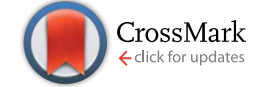

Cite this: RSC Adv., 2017, 7, 7604

Received 30th November 2016 Accepted 11th January 2017

DOI: $10.1039 / \mathrm{c} 6 \mathrm{ra} 27547 \mathrm{~h}$

www.rsc.org/advances

\title{
A fluorescent dye with large Stokes shift and high stability: synthesis and application to live cell imaging
}

\author{
Zheng Gao, ${ }^{\text {ab }}$ Yongcao Hao, ${ }^{a}$ Meiling Zheng ${ }^{a}$ and Yi Chen ${ }^{\star a}$
}

\begin{abstract}
A fluorescent dye, 2,5-bis(6-amine-benzoxazol-2-yl)thiophene (BBTA), was synthesized by a two-step reaction from starting material 2,5-bis(benzoxazol-2-yl)thiophene (BBT). BBTA exhibited strong emission and large Stokes shift in solvent, and the largest Stokes shift $\left(\Delta \lambda=186 \mathrm{~nm}\right.$ or $\left.\Delta \nu=8572 \mathrm{~cm}^{-1}\right)$ was obtained in buffer solution (PBS, $\mathrm{pH}=7.2)$ with $5 \%(\mathrm{v} / \mathrm{v})$ of polyethylene glycol monomethyl ether ( $\mathrm{mPEG}_{550}, \mathrm{MW}=550$ ) as additive. Application of BBTA to live cell imaging showed that BBTA was clearly expressed in mitochondria with high contrast. Besides, BBTA showed low cytotoxicity and excellent photo-stability.
\end{abstract}

\section{Introduction}

Development of fluorescent organic dyes with large Stokes shift and high photo-stability is essential for biological applications. ${ }^{1-3}$ Advances in fluorescent organic dyes with large Stokes shift (typically over $80 \mathrm{~nm}$ ) can minimize cross-talk between the excitation source and the fluorescent emission for cellular imaging with high signal-to-noise ratio. ${ }^{4-6}$ On the other hand, fluorescent dyes with high photo-stability are beneficial to noninvasive long-term cellular imaging, which is of great significance for investigating biological processes, pathological pathways, and therapeutic effects over long time spans. ${ }^{7-9}$

Typical fluorophore dyes such as fluorescein dyes, ${ }^{10}$ rhodamine dyes, ${ }^{11}$ cyanine dyes ${ }^{12-17}$ nile red dyes, ${ }^{18}$ and BODIPY dyes ${ }^{19,20}$ exhibit small Stokes shifts $\left(\Delta \lambda \leq 70 \mathrm{~nm}\right.$ ) (Table 1), ${ }^{21-23}$ which can reabsorb emitted photons leading to undesired background interferences. To address this issue, great effects have been dedicated and a number of noted fluorophore dyes with large Stokes shift $(\Delta \lambda \geq 80 \mathrm{~nm})$ have been developed. ${ }^{24-28}$ However, some problems are encountered with them containing complicated structures, multi-steps reaction, and low yields.

Photostability is another important parameter in evaluating the practical application of fluorescent dyes for bioimaging, and a high photostability is desirable when a fluorescent dye is used for bioimaging, especially for long-term illumination due to investigating biological processes. ${ }^{29,30}$ For most small organic fluorescent dyes, poor photostability is their common character. To enhance the photostability of organic fluorophores, nanotechnology such as conjugated nanoparticles, ${ }^{31,32}$ doped in

${ }^{a}$ Key Laboratory of Photochemical Conversion and Optoelectronic Materials, Technical Institute of Physics and Chemistry, Chinese Academy of Sciences, Beijing, 100190, China.E-mail: yichen@mail.ipc.ac.cn; Fax: +8610 6487 9375; Tel: +8610 82543595 ${ }^{b}$ University of Chinese Academy of Sciences, Beijing, 100190, China silica nanoparticles ${ }^{33,34}$ or gold nanoparticles, ${ }^{35,36}$ and doped to polymer nanoparticles ${ }^{37-39}$ is employed. In generally, nanoparticles with organic polymers or inorganic matrix can provide the encapsulated or doped dye molecules with better photostability, but some disadvantages such as complicated synthesis, easy micelle dissociation, and limited surface functionalization are contained. Therefore, direct structural modification or molecular engineering of fluorophores continues to be an active research area, and some elegant organic fluorophores with high photostability have been reported. ${ }^{\mathbf{4 0 - 4 4}}$

Benzoxazoles are one of the most important class of heterocyclic compounds, not only as key structural units of compounds with interesting biological activities ${ }^{45-47}$ but also in the field of materials chemistry. ${ }^{4-50}$ In particular, 2,5-bis(benzoxazol-2-yl) thiophene (BBT) (trade name: Uviter EBF, CAS no. 2866-43-5)

Table 1 Stokes shifts of some typical commercial fluorescent dyes ${ }^{21}$

\begin{tabular}{llllr}
\hline Compound & $\lambda_{\max }^{\mathrm{ex}}(\mathrm{nm})$ & $\lambda_{\max }^{\mathrm{em}}(\mathrm{nm})$ & $\Delta \lambda(\mathrm{nm})$ & $\Delta \nu\left(\mathrm{cm}^{-1}\right)$ \\
\hline Fluorescein & 494 & 518 & 24 & 938 \\
5-Carboxyfluorescein & 484 & 520 & 36 & 1430 \\
Fluorescein & 494 & 518 & 24 & 938 \\
isothiocyanate & & & & \\
Rhodamine 123 & 502 & 528 & 26 & 981 \\
Rhodamine 6G & 528 & 552 & 24 & 823 \\
Rhodamine Green & & & \\
Cy2 & 494 & 520 & 26 & 1012 \\
Cy3 (ref. 21) & 493 & 506 & 13 & 521 \\
Cy5 (ref. 22) & 550 & 570 & 20 & 638 \\
Nile red & 650 & 670 & 20 & 459 \\
BODIPY 493 & 580 & 650 & 70 & 1856 \\
BODIPY 505 & 494 & 504 & 10 & 401 \\
Mito-Tracker Green & 502 & 512 & 10 & 389 \\
Mito-Tracker Red & 490 & 516 & 26 & 1028 \\
& 579 & 599 & 20 & 577
\end{tabular}




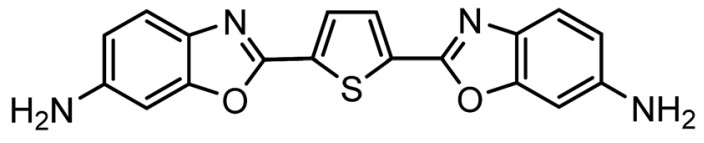

BBTA

Scheme 1 Chemical structure BBTA.

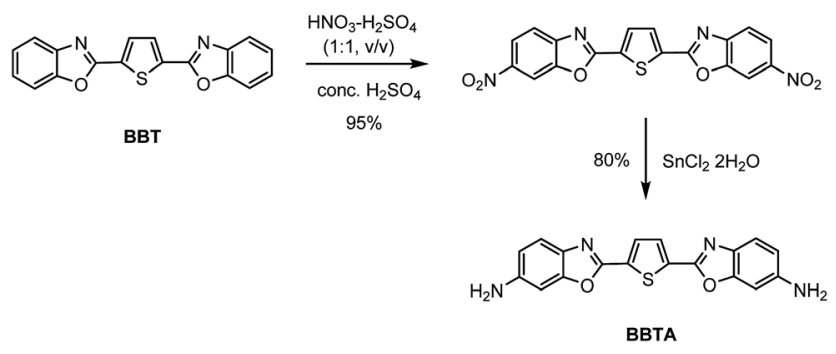

Scheme 2 Synthetic route for BBTA.

(chemical structure see Scheme 2) and its derivatives are wellknown fluorescent dyes used as whitening agents ${ }^{51,52}$ and various optoelectronic applications $\mathrm{s}^{53-55}$ due to strong emission and high photo-stability. Herein, a new derivative 2,5-bis(6amine-benzoxazol-2-yl)thiophene (BBTA) ${ }^{56}$ (Scheme 1) has been synthesized by a two-step reaction starting from BBT (synthetic route see Scheme 2). BBTA exhibits very large Stokes shift and excellent photo-stability in buffer solution (with $5 \%$ of $\mathrm{mPEG}_{550}$ as cosolvent) which is beneficial to biological imaging. Using HeLa cells as prototype, BBTA can be clearly expressed in mitochondria with high contrast.

\section{Experimental}

\section{Synthesis}

(a) To a solution of 2,5-bis(benzoxazol-2-yl)thiophene (BBT, ${ }^{57}$ $3.18 \mathrm{~g}, 10 \mathrm{mmol})$ in conc. $\mathrm{H}_{2} \mathrm{SO}_{4}(98 \%, 20 \mathrm{~mL})$ was dropwise added the mixture of $\mathrm{HNO}_{3}(65 \%)$ and $\mathrm{H}_{2} \mathrm{SO}_{4}(98 \%)(1: 1, \mathrm{v} / \mathrm{v}$, $1.3 \mathrm{~mL}$ ) at $0{ }^{\circ} \mathrm{C}$. The mixture was stirred at $0{ }^{\circ} \mathrm{C}$ for $1 \mathrm{~h}$, and then slowly poured into ice water $(30 \mathrm{~mL})$. The cold mixture solution was stirred slowly at ambient temperature until yellow precipitate was produced completely. The yellow product was filtered off, washed with water $(3 \times 30 \mathrm{~mL})$, and dried under vacuum. The crude product (2,5-bis(6-nitrobenzoxazol-2-yl) thiophene) was obtained in yield of $95 \%$ and used for the next step without further purification. (b) To the solution of 2,5bis(6-nitrobenzoxazol-2-yl)thiophene $(1.02 \mathrm{~g}, 2.5 \mathrm{mmol})$ in EtOH $(20 \mathrm{~mL})$ was added $\mathrm{SnCl}_{2} \cdot 2 \mathrm{H}_{2} \mathrm{O}(5.6 \mathrm{~g}, 25 \mathrm{mmol})$. The mixture was refluxed till the starting material was disappeared checked by TLC $\left(R_{\mathrm{f}}=0.51\right.$, eluent: PE/EtOAc $\left.=2: 1, \mathrm{v} / \mathrm{v}\right)$. After cooled to ambient temperature, the mixture solution was then slowly poured into water $(200 \mathrm{~mL})$, extracted with $\mathrm{CH}_{2} \mathrm{Cl}_{2}(5 \times 30 \mathrm{~mL})$. The combined organic solution was dried over anhydrous $\mathrm{Na}_{2} \mathrm{SO}_{4}$, after evaporation of the solvent, the crude product was purified by flash column chromatography $(\mathrm{PE} / \mathrm{EtOAc}=1: 1, \mathrm{v} / \mathrm{v}$, PE: $\left.40-60{ }^{\circ} \mathrm{C}\right)$ to afford BBTA $(0.70 \mathrm{~g})$ in yield of $80 \%, R_{\mathrm{f}}=0.55$ (eluent: EtOAc). ${ }^{1} \mathrm{H}$ NMR (400 MHz, DMSO- $\left.d_{6}\right): \delta(\mathrm{ppm}) 7.95$ (s, $2 \mathrm{H}), 7.65(\mathrm{~d}, J=15.6 \mathrm{~Hz}, 2 \mathrm{H}), 7.21(\mathrm{~s}, 2 \mathrm{H}), 6.98(\mathrm{~d}, J=8.4 \mathrm{~Hz}$, 2H), 3.76 (brs, $4 \mathrm{H}) .{ }^{13} \mathrm{C}$ NMR (100 MHz, DMSO- $d_{6}$ ): $\delta$ (ppm) 156.8, 152.8, 147.9, 132.7, 130.5, 120.9, 115.0, 96.5. HRMS (EI $\left.{ }^{+}\right)$ calcd for $\mathrm{C}_{18} \mathrm{H}_{12} \mathrm{~N}_{4} \mathrm{O}_{2} \mathrm{~S}\left(\mathrm{M}^{+}\right)$: 348.0681. Found: 348.0682. IR $\left(\mathrm{cm}^{-1}\right)$ : 3406, 2904, 1606, 1534, 1141, 1048.

\section{Cell culture and fluorescence images}

For the fluorescence imaging in live cells, HeLa cells are cultured in culture media Dulbecco's Modified Eagle's Medium (DMEM/F12 $1: 1$ (HyClone) with 10\% Fetal Bovine Serum (FBS) and $1 \%$ penicillin-streptomycin) at $37{ }^{\circ} \mathrm{C}$ under a humidified atmosphere containing $5 \% \mathrm{CO}_{2}$ for $24 \mathrm{~h}$. The cells were seeded on a $\varnothing 35 \mathrm{~mm}$ glass-bottomed dish (NEST) for live-cell imaging by confocal laser scanning microscopy (CLSM). The HeLa cells were treated with $1 \mu \mathrm{M}$ of BBTA in $2 \mathrm{~mL}$ of serum free medium for $2 \mathrm{~h}$ and imaged by CLSM without removing the molecule in the cell medium. Confocal fluorescence imaging was performed with Nikon multiphoton microscopy (A1R MP) with a $60 \times$ oilimmersion objective lens and living cell work station. The cellular images were taken under a CLSM by using the excitation channel at $488 \mathrm{~nm}$.

\section{Toxicity test}

Toxicity test of HeLa cells incubated with BBTA is carried out as follows: (a) HeLa cells were incubated with $1 \mu \mathrm{M}$ of BBTA for $2 \mathrm{~h}$, after washed up 3 times with phosphate buffered saline (PBS), $1 \mathrm{~mL}$ of fresh PBS was added. (b) To the incubated HeLa cells in PBS was added propidium iodide (PI) probe, after incubation for $10 \mathrm{~min}$, the HeLa cells with BBTA and PI probe were washed up with PBS for three times, $500 \mu \mathrm{L}$ of fresh PBS was then added. (c) The sample was observed by Nikon A1R confocal fluorescence microscope with excitation wavelength of $488 \mathrm{~nm}$ and $561 \mathrm{~nm}$, respectively, and the range of collected fluorescence is $500-560 \mathrm{~nm}$ and 570-620 nm, respectively. (d) The number of dead cells (red) and the whole number of cells were counted from the obtained images. Around 200 cells were counted, and the ratio of living cells (viability, \%) was calculated. The viability of the cells without incubation of BBTA was also checked by PI under the same experimental condition. The viability (\%) of stained cells is calculated by relation to that of unstained cells in which the viability of unstained cells is set to $100 \%$.

\section{Material and methods}

${ }^{1} \mathrm{H}$ and ${ }^{13} \mathrm{C}$ NMR spectra are recorded at 400 and $100 \mathrm{MHz}$, respectively, with TMS as an internal reference. HRMS spectra are recorded with MS spectrometer (Waters, GCT Premier). UV absorption spectra and fluorescence spectra are measured with an absorption spectrophotometer (Hitachi U-3010) and a fluorescence spectrophotometer (F-2500), respectively. All experiments are carried out with commercially available reagents and solvents, and used without further purification, unless otherwise noted. 


\section{Results and discussion}

BBTA was obtained by a two-step reaction starting from BBT, which was nitrified first and reduced followed (Scheme 2). Treatment BBT with nitric acid (65\%, wt\%) in conc. $\mathrm{H}_{2} \mathrm{SO}_{4}$ (98\%, wt $\%)$ at $0{ }^{\circ} \mathrm{C}$ provided crude product 2,5-bis(6nitrobenzoxazol-2-yl)thiophene in yield of $95 \%$. The crude 2,5-bis(6-nitrobenzoxazol-2-yl)thiophene was then reduced by $\mathrm{SnCl}_{2} \cdot 2 \mathrm{H}_{2} \mathrm{O}$ in ethanol at $80{ }^{\circ} \mathrm{C}$ to yield target compound 2,5-bis(6-amine-benzoxazol-2-yl)thiophene BBTA in $80 \%$ isolated yield. The details of procedure and the structure characterization of BBTA see Experimental section.

Both absorption and fluorescence of BBTA in different organic solvents were measured. As shown in Table 2, the fluorescence of BBTA depended on both polarity and proticity of solvents. In apolar solvent (toluene) or small polar solvent (DCM), BBTA showed a green emission with the maximum emission around at $500 \mathrm{~nm}$, but in polar solvent (DMSO) or protic solvent (EtOH), an orange emission (558 $\mathrm{nm}$ for DMSO, $550 \mathrm{~nm}$ for EtOH) was obtained. The large bathochromic shifts of BBTA with polarity or proticity of solvents suggested that BBTA in the excited stated exhibited large polarity, which resulted in more affected by polar solvents or protic solvents. Besides, significant fluorescence quenching was also obtained in large polar solvents or protic solvents, as shown in Table 2, the fluorescence quantum yield $\left(\Phi_{\mathrm{f}}\right)$ was decreased from 0.99 in toluene to 0.33 in DMSO or 0.32 in $\mathrm{EtOH}$, which probably resulted from the narrowing of the singlet-triplet energy gap in large polar solvents, and favoured internal conversion ${ }^{58}$ or intersystem crossing to the triplet state. ${ }^{59}$

Absorbance and fluorescence of BBTA $(20 \mu \mathrm{M})$ in PBS buffer solution ( $\mathrm{NaCl} 137 \mathrm{mmol} \mathrm{L}^{-1}, \mathrm{KCl} 2.7 \mathrm{mmol} \mathrm{L}{ }^{-1}, \mathrm{Na}_{2} \mathrm{HPO}_{4}$ $\left.10 \mathrm{mmol} \mathrm{L}^{-1}, \mathrm{KH}_{2} \mathrm{PO}_{4} 2 \mathrm{mmol} \mathrm{L}{ }^{-1}, \mathrm{pH}=7.2\right)$ were also measured. To enhance aqueous solubility, $5 \%(\mathrm{v} / \mathrm{v})$ of polyethylene glycol monomethyl ether $\left(\mathrm{mPEG}_{550}, \mathrm{MW}=550\right)$ as additive was added. The maximum absorption of BBTA was shifted to $\lambda_{\max }=382 \mathrm{~nm}$ with a large extinction coefficient $(\varepsilon=$ $\left.1.2 \times 10^{4} \mathrm{~cm}^{-1} \mathrm{M}^{-1}\right)$. As compared to the $\lambda_{\max }$ of BBTA in organic solvents (Table 1$)$, a large blue-shift $(\Delta \lambda \geq 22 \mathrm{~nm})$ was obtained, which probably resulted from the aggregation of BBTA in PBS because of PPEG $_{550}$. To confirm the suggestion,

Table 2 Optical data of BBTA in different solvents $(10 \mu \mathrm{M})$ at $25^{\circ} \mathrm{C}^{a}$

\begin{tabular}{lllllll}
\hline Solvent & $\begin{array}{l}\lambda_{\text {max }} \\
(\mathrm{nm})\end{array}$ & $\begin{array}{l}\varepsilon_{\text {max }} \\
\left(\mathrm{M}^{-1} \mathrm{~cm}^{-1}\right)\end{array}$ & $\begin{array}{l}\lambda_{\mathrm{em}} \\
(\mathrm{nm})\end{array}$ & $\Phi_{\mathrm{f}}{ }^{d}$ & $\begin{array}{l}\Delta \lambda \\
(\mathrm{nm})\end{array}$ & $\begin{array}{l}\Delta \nu \\
\left(\mathrm{cm}^{-1}\right)\end{array}$ \\
\hline $\mathrm{C}_{7} \mathrm{H}_{8}$ & 405 & $6.6 \times 10^{3}$ & 495 & 0.99 & 90 & 4489 \\
$\mathrm{CH}_{2} \mathrm{Cl}_{2}$ & 404 & $1.0 \times 10^{4}$ & 505 & 0.94 & 101 & 4950 \\
$\mathrm{MeCN}$ & 406 & $1.4 \times 10^{4}$ & 534 & 0.73 & 128 & 5904 \\
$\mathrm{EtOH}$ & 420 & $1.3 \times 10^{4}$ & 550 & 0.30 & 130 & 5627 \\
$\mathrm{DMSO}$ & 436 & $1.4 \times 10^{4}$ & 558 & 0.33 & 122 & 5015 \\
$\mathrm{PBS}^{b}$ & 382 & $1.2 \times 10^{4}$ & 568 & 0.11 & 186 & 8572 \\
PBS $^{c}$ & 405 & $1.2 \times 10^{4}$ & 568 & 0.13 & 163 & 7085
\end{tabular}

${ }^{a} \mathrm{C}_{7} \mathrm{H}_{8}$ : toluene; MeCN: acetonitrile; EtOH: ethanol; DMSO: dimethyl sulfoxide. ${ }^{b}$ PBS: PBS- PEEG $_{550}$ (95:5, v/v). ${ }^{c}$ PBS: PBS-DMSO (99: 1 , $\mathrm{v} / \mathrm{v}) .{ }^{d} \Phi_{\mathrm{f}}$ : fluorescence quantum yield using fluorescein $\left(\Phi_{\mathrm{f}}=0.95\right.$, $0.1 \mathrm{M} \mathrm{NaOH})$ as reference.

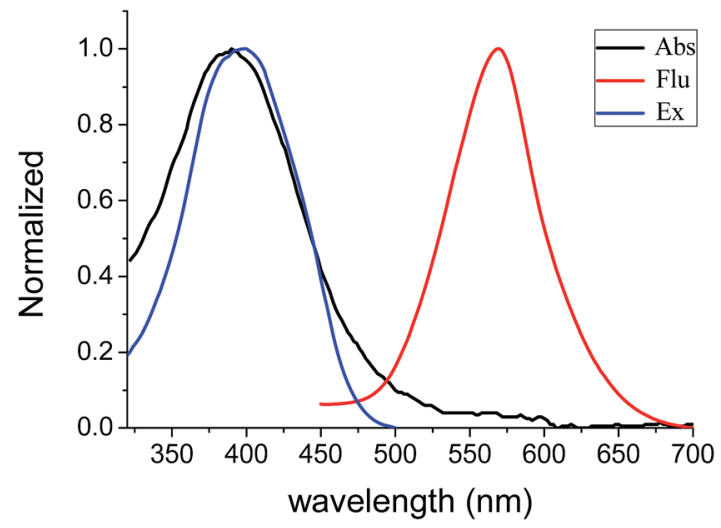

Fig. 1 Absorption, excitation $(20 \mu \mathrm{M})$ and fluorescence $(10 \mu \mathrm{M})$ spectral of BBTA in PBS-mPEG $550(95: 5, \mathrm{v} / \mathrm{v}), \lambda_{\mathrm{ex}}=405 \mathrm{~nm}$.

the control experiment was performed using PBS replaced PBS- PPEG $_{550}$. A stock solution of BBTA in DMSO $\left(1 \mathrm{mg} \mathrm{mL} \mathrm{mL}^{-1}\right)$ was prepared and diluted with PBS to $10 \mu \mathrm{M}$. It was found that the absorption of BBTA appeared at $\lambda_{\max }=405 \mathrm{~nm}$ in PBS solution, which is similar to that in organic solvents. Besides, both absorption and excitation spectral in PBS- PPEG $_{550}$ (95: 5 , $\mathrm{v} / \mathrm{v}$ ) almost overlapped (Fig. 1), which also indicated that the aggregation was formed in ground state. Upon excitation with $405 \mathrm{~nm}$ light, an orange fluorescence $\left(\lambda_{\mathrm{em}}=568 \mathrm{~nm}\right)$ was observed, and a moderate fluorescence quantum yield $\left(\Phi_{\mathrm{f}}=\right.$ $0.11)$ was obtained by using fluorescein $\left(\Phi_{\mathrm{f}}=0.95,0.1 \mathrm{M} \mathrm{NaOH}\right)$ as reference. As shown in Fig. 1, the overlap between the absorption and fluorescence spectral was very small, and a very large Stokes shift $\left(\Delta \lambda=186 \mathrm{~nm}\right.$, or $\left.\Delta \nu=8572 \mathrm{~cm}^{-1}\right)$ was obtained as compared to that of typical commercial fluorescent dyes (Table 1). The large Stokes shift is beneficial to practical application since it can reduce self-quenching that is resulting from molecular self-absorption.

BBTA applied to fluorescence imaging in living cells was explored. HeLa living cells were incubated with BBTA $(1.0 \mu \mathrm{M})$ in PBS solution (with $5 \%$ of $\mathrm{mPEG}_{550}$ ) for $2 \mathrm{~h}$, and the images of the live cells were taken by using a confocal laser scanning microscope (CLSM). Upon excitation with $488 \mathrm{~nm}$ and recorded at channel (500-550 nm), HeLa cells incubated with BBTA showed fluorescence signal, as shown in Fig. 2, the fluorescence images indicated that BBTA was clearly expressed in HeLa cells. It is worth noting that an enhanced fluorescence was observed when BBTA combined with HeLa living cells, as a consequence,

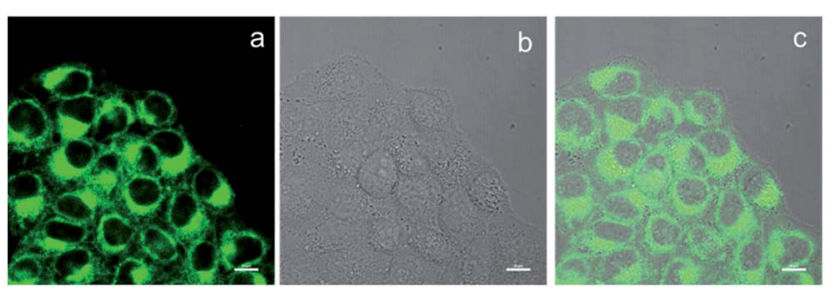

Fig. 2 CLSM images of HeLa cells. (a) Fluorescence imaging incubated with BBTA; (b) bright field imaging; (c) merged imaging. Scale bars: 10 $\mu \mathrm{m}$. 
HeLa cells incubated with BBTA could be directly used for microscopic images without washing up by phosphate-buffered saline (PBS). As presented in Fig. 2, no significant background interference was detected when the incubated HeLa cells was used for microscopic images without washing up.

To determine the cellular localization of BBTA, the co-localization experiment with Mito Tracker Deep Red was performed. HeLa cells were incubated with $1.0 \mu \mathrm{M}$ of BBTA for $2 \mathrm{~h}$, followed by incubation with $25 \mathrm{nM}$ of Mito Tracker Deep Red for $20 \mathrm{~min}$. Both $488 \mathrm{~nm}$ and $640 \mathrm{~nm}$ excitation wavelength were employed for BBTA and Mito Tracker Deep Red, respectively, and the fluorescence was recorded at channel (500-550 $\mathrm{nm})$ and (670-720 nm), respectively. As presented in Fig. 3, the image with the probe is in good agreement with that of the commercial Mito Tracker Deep Red, and the overlaid confocal fluorescence images of both BBTA and Mito Tracker Deep Red demonstrated that BBTA was expressed in mitochondria.

Discrimination against background fluorescence of HeLa cells was also conducted. Both fluorescence imaging from incubated HeLa cells with BBTA $(1.0 \mu \mathrm{M})$ and from background fluorescence imaging were obtained by using a confocal laser scanning microscope. As is demonstrated in Fig. 4, with excitation at $488 \mathrm{~nm}$ and recorded at channel (500-550 $\mathrm{nm}$ ), both HeLa cells with and without incubation with BBTA showed fluorescence signal, the auto-fluorescence of HeLa cells showed, however, much weaker than that of incubated HeLa cells, and a high contrast in fluorescence imaging was obtained. As shown in Fig. 4, the auto-fluorescence signal was hardly identified after the HeLa cells were incubated with BBTA.

Both $\mathrm{pH}$-sensitivity and photo-stability are important features of a probe used for biological applications. pH-Sensitivity of BBTA was performed in $\mathrm{H}_{2} \mathrm{O}-\mathrm{mPEG}_{550}(95: 5, \mathrm{v} / \mathrm{v})$ solution by adjusting with $\mathrm{HCl}$ or $\mathrm{NaOH}$ aqueous solution, respectively. As
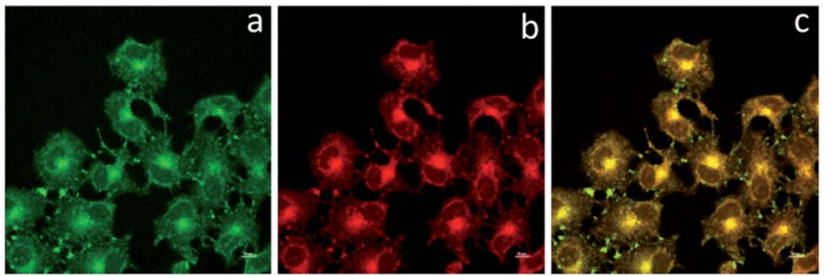

Fig. 3 CLSM images of HeLa cells. (a) Fluorescence imaging incubated with BBTA; (b) fluorescence imaging incubated with Mito Tracker Deep Red; (c) merged imaging. Scale bars: $10 \mu \mathrm{m}$.
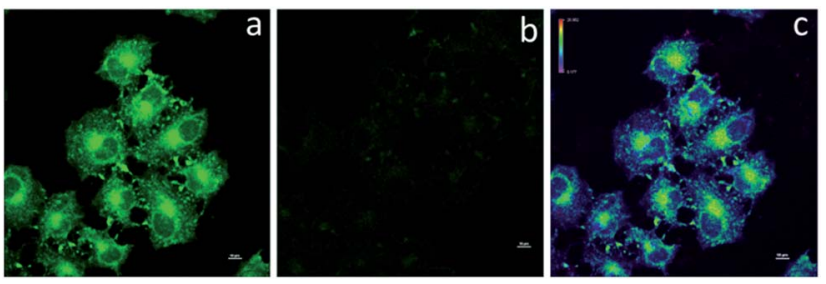

Fig. 4 CLSM images of HeLa cells. (a) Fluorescence imaging incubated with BBTA; (b) auto-fluorescence imaging; (c) merged imaging. Scale bars are $10 \mu \mathrm{m}$.

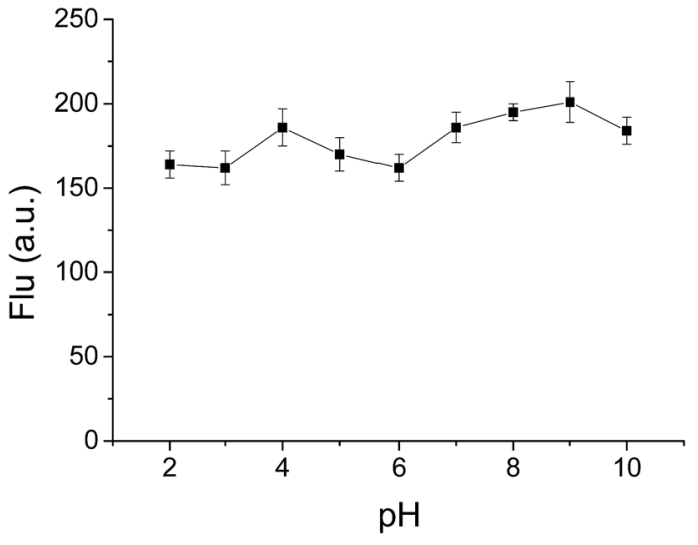

Fig. 5 Fluorescence intensity of BBTA in $\mathrm{H}_{2} \mathrm{O}-\mathrm{mPEG}_{550}(95: 5, \mathrm{v} / \mathrm{v}, 10$ $\mu \mathrm{M})$ with different $\mathrm{pH}$ (error bar represents standard deviation). $\lambda_{\mathrm{ex}}=$ $405 \mathrm{~nm}$.

displayed in Fig. 5, no distinct fluorescence quenching was observed at emission peak (detection at $\lambda_{\mathrm{em}}=568 \mathrm{~nm}$ ) with different $\mathrm{pH}$ range from 2 to 10 . Besides, it was also found that no obvious change in both absorption spectral (wavelength and optical density) and emission wavelength was detected when the $\mathrm{pH}$ of the solution changed from 2 to 10, which demonstrated that BBTA is stable in aqueous solution over a wide $\mathrm{pH}$ range, and beneficial for potential bioimaging application in physiological environments.

The photo-stability of BBTA was investigated in both PBS$\mathrm{mPEG}_{550}(95: 5, \mathrm{v} / \mathrm{v})$ aqueous solution and living cells, respectively. Fig. 6 represented the absorption changes of BBTA in PBS- PEG $_{330}(95: 5, \mathrm{v} / \mathrm{v})$ aqueous solution as a function of irradiating time with $365 \mathrm{~nm}$ light (power: $36 \mathrm{~W}$, energy: $3.7 \mathrm{~mW}$ $\mathrm{cm}^{-2}$ ). It was found that no significant change in optical density at $\lambda_{\max }=382 \mathrm{~nm}$ was detected when the BBTA solution was irradiated for $60 \mathrm{~min}$, as shown in Fig. 6, less than $0.1 \%$ of degradation was detected (calculation by the change in optical density). To compare the photostability, a commercial fluorescent organic dye rhodamine $\mathrm{B}$ was employed for control

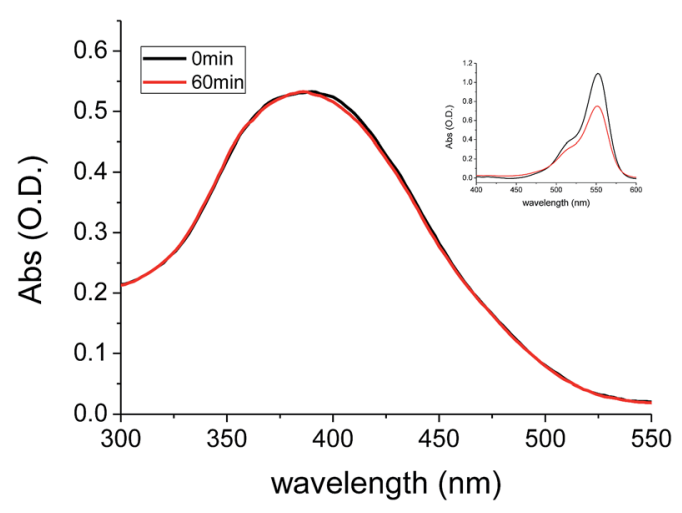

Fig. 6 Absorption changes of BBTA in PBS-mPEG 550 (95:5, v/v, 10 $\mu \mathrm{M})$ with $365 \mathrm{~nm}$ light irradiation (periods: 0 and $60 \mathrm{~min}$; power: $36 \mathrm{~W}$, energy: $3.7 \mathrm{~mW} \mathrm{~cm}^{-2}$ ). Inset: absorption change of rhodamine $B$ in PBS-mPEG $550(95: 5, v / v, 10 \mu \mathrm{M})$ with $365 \mathrm{~nm}$ light irradiation (periods: 0 and $60 \mathrm{~min}$; power: $36 \mathrm{~W}$, energy: $3.7 \mathrm{~mW} \mathrm{~cm}^{-2}$ ). 
experiment. As shown in Fig. 6 (inset) more than 30\% degradation was obtained upon irradiation of rhodamine B in PBSmPEG $_{550}(95: 5, \mathrm{v} / \mathrm{v})$ solution for $60 \mathrm{~min}$. This suggested that the BBTA showed excellent photo-degradation resistance. Meanwhile, no significant change in fluorescence intensity was observed when the solution was irradiated for 60 min under $365 \mathrm{~nm}$ light.

The photo-stability of BBTA in living cells was explored by continuous laser exposure using confocal laser scanning microscopy. After scanning for $10 \mathrm{~min}$, no significant change in the CLSM images was obtained (Fig. 7), which indicated that BBTA exhibits high photo-stability for bioimaging.

The high photo-stability of BBTA probably results from oxygen depletion. It is known that the rate of triplet state quenching by molecular oxygen is faster than the formation of radical states in the absence of high concentrations of oxidants or reductants. The fluorescence of BBTA in PBS was much smaller than that in organic solvents such as toluene or $\mathrm{CH}_{2} \mathrm{Cl}_{2}$. The major competitive fluorescence quenching pathway of 2,5bis(benzoxazol-2-yl)thiophene unit was demonstrated ${ }^{60}$ by intersystem crossing to the triplet state. Oxygen consumption by triplet state may benefit to photostability of BBTA.

Toxicity is an important factor to evaluate the application possibility of fluorescence dyes. To test the cytotoxicity of BBTA, propidium iodide (PI, Invitrogen, P3566), which is widely used in the toxicity study for identifying dead cells in a population, was employed as the probe for the detection of dead cells of HeLa. The HeLa cells incubated with BBTA and PI probe were excited by $488 \mathrm{~nm}$ and $561 \mathrm{~nm}$, respectively, and observed by Nikon A1R confocal fluorescence microscope with the
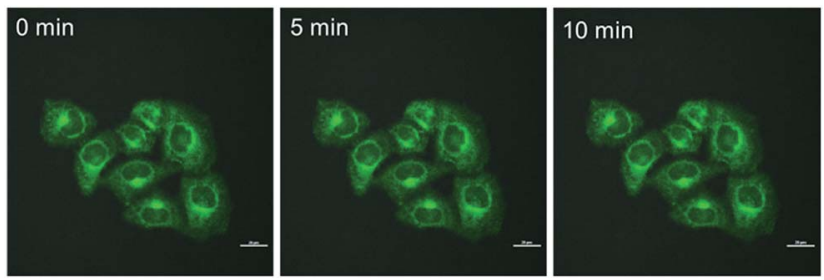

Fig. 7 CLSM images of HeLa cells incubated with BBTA with increasing scanning times (0-10 min). Scale bars: $10 \mu \mathrm{m}$.

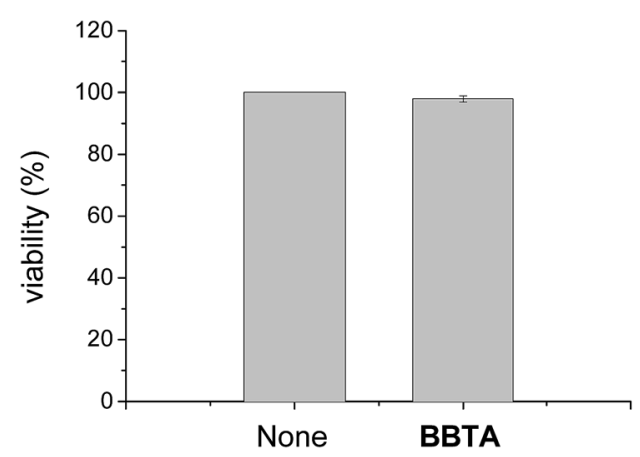

Fig. 8 The viability of HeLa cells with (right column) and without (left column) incubation with BBTA $(1.0 \mu \mathrm{M})$ for $2 \mathrm{~h}$ (error bar represents standard deviation). fluorescence recorded at channel (500-550 nm) and (570-620 $\mathrm{nm}$ ), respectively. The number of dead cells and the whole number of cells were counted from the obtained images, and the viability (\%) (the ratio of living cells) was calculated by the comparison of the number of living cells with that of the dead cells. As shown in Fig. 8, more than $98 \%$ of viability was obtained when the HeLa cells were incubated with BBTA $(1.0 \mu \mathrm{M})$ within $2 \mathrm{~h}$. The preliminary result indicated that BBTA showed low cytotoxicity at the concentration used for cell imaging.

\section{Conclusions}

In summary, a new fluorescent organic dye based on 2,5bis(benzoxazol-2-yl)thiophene derivative has been developed and its application to living cells imaging has been demonstrated. The fluorescence dye has some distinct advantages including facile preparation, high yield, large Stokes shift and excellent photo-stability, which benefits the biological fluorescence imaging.

\section{Acknowledgements}

This work was supported by the National Natural Science Foundation of China (No. 21572241 and No. 61475164).

\section{Notes and references}

1 L. D. Lavis and R. T. Raines, ACS Chem. Biol., 2014, 9, 855.

2 L. D. Lavis and R. T. Raines, ACS Chem. Biol., 2008, 3, 142.

3 K. Li, W. Qin, D. Ding, N. Tomczak, J. Geng, R. Liu, J. Liu, X. Zhang, H. Liu, B. Liu and B. Z. Tang, Sci. Rep., 2013, 3, 1150.

4 X. Wu, X. Sun, Z. Guo, J. Tang, Y. Shen, T. D. James, H. Tian and W. Zhu, J. Am. Chem. Soc., 2014, 136, 3579.

5 J. F. Araneda, W. E. Piers, B. Heyne, M. Parvez and R. McDonald, Angew. Chem., Int. Ed., 2011, 50, 12214.

6 D. M. Shcherbakova, M. A. Hink, L. Joosen, T. W. J. Gadella and V. V. Verkhusha, J. Am. Chem. Soc., 2012, 134, 7913.

7 Q. Ye, S. Chen, D. Zhu, X. Lu and Q. Lu, J. Mater. Chem. B, 2015, 3, 3091.

8 Z. Wang, S. Chen, J. W. Y. Lam, W. Qin, R. T. K. Kwok, N. Xie, Q. Hu and B. Z. Tang, J. Am. Chem. Soc., 2013, 135, 8238.

9 J. K. Jaiswal, H. Mattoussi, J. M. Mauro and S. M. Simon, Nat. Biotechnol., 2002, 21, 47.

10 Y. Duan, M. Liu, W. Sun, M. Wang, S. Liu and Q. X. Li, MiniRev. Org. Chem., 2009, 6, 35.

11 M. Beija, C. A. M. Afonso and J. M. G. Martinho, Chem. Soc. Rev., 2009, 38, 2410.

12 A. P. Gorka, R. R. Nani and M. J. Schnermann, Org. Biomol. Chem., 2015, 13, 7584.

13 J. L. Bricks, A. D. Kachkovshii, Y. L. Slominskii, A. O. Gerasov and S. V. Popov, Dyes Pigm., 2015, 121, 238.

14 M. Henary and A. Levitz, Dyes Pigm., 2013, 99, 1107.

15 M. Panigrahi, S. Dash, S. Patel and B. K. Mishra, Tetrahedron, 2012, 68, 781.

16 A. Mishra, R. K. Behera, P. K. Behera, B. K. Mishra and G. B. Behera, Chem. Rev., 2000, 100, 1973. 
17 M. Levitus and S. Ranjit, Q. Rev. Biophys., 2011, 44, 123.

18 J. Jose and K. Burgess, Tetrahedron, 2006, 62, 11021.

19 G. Ulrich, R. Ziessel and A. Harriman, Angew. Chem., Int. Ed., 2008, 47, 1184.

20 Y. Ni and J. Wu, Org. Biomol. Chem., 2014, 12, 3774.

21 Y. Hayashi, N. Obata, M. Tamaru, S. Yamaguchi, Y. Matsuo,

A. Saeki, S. Seki, Y. Kureishi, S. Saito, S. Yamaguchi and H. Shinokubo, Org. Lett., 2012, 14, 866.

22 B. K. Nunnally, H. He, L.-C. Li, S. A. Tucker and L. B. McGown, Anal. Chem., 1997, 69, 2392.

23 K. Jia, Y. Wan, A. Xia, S. Li, F. Gong and G. Yang, J. Phys. Chem. A, 2007, 111, 1593.

24 M. M. Bishop, J. D. Roscioli, S. Ghosh, J. J. Mueller, N. C. Shepherd and W. F. Beck, J. Phys. Chem. B, 2015, 119, 6905.

25 M. Vendrell, D. Zhai, J. C. Er and Y. Chang, Chem. Rev., 2012, 112, 4391.

26 X. Wang and O. S. Wolfbeis, Chem. Soc. Rev., 2014, 43, 3665.

27 N. Boens, V. Leen and W. Dehaen, Chem. Soc. Rev., 2012, 41, 1130.

28 Q. Huaulmé, M. Mirloup, P. Retailleau and R. Ziessel, Org. Lett., 2015, 17, 2246.

29 X. Wu and W. Zhu, Chem. Soc. Rev., 2015, 44, 4179.

30 Q. Zhang, M. F. Juette, S. Jockusch, M. R. Wasserman, Z. Zhou, R. B. Altmana and S. C. Blanchard, Chem. Soc. Rev., 2014, 43, 1044.

31 J. Jose and K. Burgess, J. Org. Chem., 2006, 71, 7835.

32 D. T. Reilly, S. H. Kim, J. A. Katzenellenbogen and C. M. Schroeder, Anal. Chem., 2015, 87, 11048.

33 Y. Yang, X. Wang, Q. Cui, Q. Cao and L. Li, ACS Appl. Mater. Interfaces, 2016, 8, 7440.

34 A. Pedone, G. Prampolini, S. Monti and V. Barone, Chem. Mater., 2011, 23, 5016.

35 Y. Zhong, F. Peng, F. Bao, S. Wang, X. Ji, L. Yang, Y. Su, S.-T. Lee and Y. He, J. Am. Chem. Soc., 2013, 135, 8350.

36 J. E. Donehue, E. Wertz, C. N. Talicska and J. S. Biteen, J. Phys. Chem. C, 2014, 118, 15027.

37 C.-A. J. Lin, T.-Y. Yang, C.-H. Lee, S. H. Huang, R. A. Sperling, M. Zanella, J. K. Li, J.-L. Shen, H.-H. Wang, H.-I. Yeh, W. J. Parak and W. H. Chang, ACS Nano, 2009, 3, 395.

38 C. Wu, Y. Zheng, C. Szymanski and J. McNeill, J. Phys. Chem. $C, 2008,112,1772$.

39 Z. Tian, J. Yu, X. Wang, L. C. Groff, J. L. Grimland and J. D. McNeill, J. Phys. Chem. B, 2013, 117, 4517.

40 C. Jiao, K.-W. Huang and J. Wu, Org. Lett., 2011, 13, 632.

41 N. I. Shank, H. H. Pham, A. S. Waggoner and B. A. Armitage, J. Am. Chem. Soc., 2013, 135, 242.
42 T. Inari, M. Yamano, A. Hirano, K. Sugawa and J. Otsuki, J. Phys. Chem. A, 2014, 118, 5178.

43 Z. Yuan, A. H. Younes, J. R. Allen, M. W. Davidson and L. Zhu, J. Org. Chem., 2015, 80, 5600.

44 W. Liu, B. Zhou, G. Niu, J. Ge, J. Wu, H. Zhang, H. Xu and P. Wang, ACS Appl. Mater. Interfaces, 2015, 7, 7421.

45 K. Seth, S. K. Garg, R. Kumar, P. Purohit, V. S. Meena, R. Goyal, U. C. Banerjee and A. K. Chakraborti, ACS Med. Chem. Lett., 2014, 5, 512.

46 Y. Sato, M. Yamada, S. Yoshida, T. Soneda, M. Ishikawa, T. Nizato, K. Suzuki and F. Konno, J. Med. Chem., 1998, 41, 3015.

47 S. K. Gorla, M. Kavitha, M. Zhang, J. E. W. Chin, X. Liu, B. Striepen, M. Makowska-Grzyska, Y. Kim, A. Joachimiak, L. Hedstrom and G. D. Cuny, J. Med. Chem., 2013, 56, 4028.

48 M. Calle, C. M. Doherty, A. J. Hill and Y. M. Lee, Macromolecules, 2013, 46, 8179.

49 T. Agag, J. Liu, R. Graf, H. W. Spiess and H. Ishida, Macromolecules, 2012, 45, 8991.

50 H. A. Patel, D. Ko and C. T. Yavuz, Chem. Mater., 2014, 26, 6729.

51 I. M. Ward, in Structure and properties of oriented polymers, Applied Science Publishers, London, 1975, 1st edn, pp. 1500.

52 M. O. Liu, H. F. Lin, M. C. Yang, M. J. Lai, C. C. Chang, H. C. Liu, P. L. Shiao, I. M. Chen and J. Y. Chen, Mater. Lett., 2006, 60, 2132.

53 S. S. Babu, V. K. Praveen and A. Ajayaghosh, Chem. Rev., 2014, 114, 1973.

54 U. Mitschke and P. BaÈuerle, J. Mater. Chem., 2000, 10, 1471. 55 Y. Hao, M. Zheng and Y. Chen, J. Mater. Chem. B, 2014, 2, 7369.

56 Application number: JP 1991-219950. Full text is accessible through: https://www.j-platpat.inpit.go.jp/web/all/top/ BTmTopEnglishPage.

57 F. Shibahara, E. Yamaguchi and T. Murai, Chem. Commun., 2010, 46, 2471.

58 Y. Liu, M. Nishiura, Y. Wang and Z. Hou, J. Am. Chem. Soc., 2006, 128, 5592.

59 M. V. Skorobogatyi, A. A. Pchelintseva, A. L. Petrunina, I. A. Stepanova, V. L. Andronova, G. A. Galegov, A. D. Malakhov and V. A. Korshun, Tetrahedron, 2006, 62, 1279.

60 M. A. Fourati, T. Maris, W. G. Skene, C. G. Bazuin and R. E. Prud'homme, J. Phys. Chem. B, 2011, 115, 12362. 